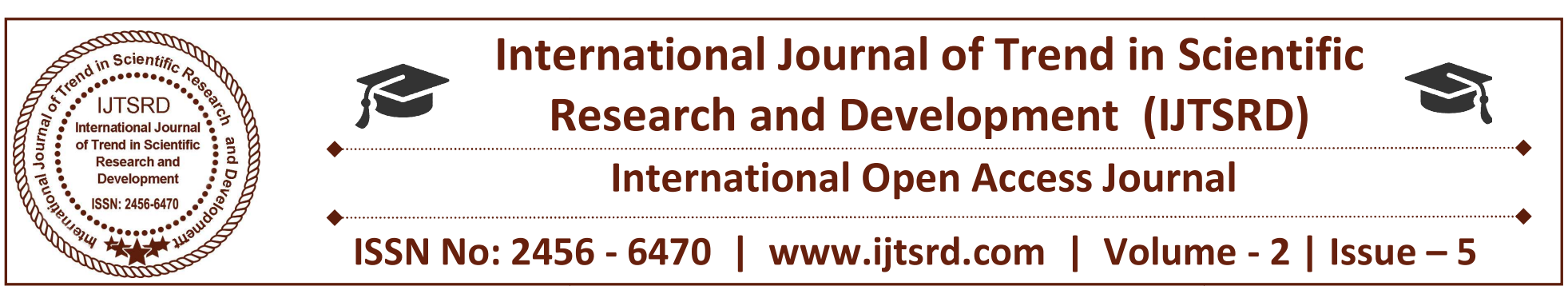

\title{
Child Labour : A Devastating Evil and Measures Taken by Indian Judiciary
}

\author{
Diwanshi Singh Chandel \\ B.A., L.L.B. (hons), Indore Institute of Law, \\ Indore, Madhya Pradesh, India
}

\section{ABSTRACT}

Child labour is not a new issue for India. With the increasing population, the problem and issue of Child labour is also increasing. India is the second largest country after Africa which is adversely affected by child labour. Our government took many measures to eliminate child labour. Child labour is basically a kind of work which deprives the children from their childhood; it can be any kind of work like working in tea stall, working in fireworks etc. According to Article 24 of Indian constitution no children below the age of 14 can be employed in any factory or in any hazardous activity. Poverty, unemployment, lack of educational facilities, social economic backwardness is some of the reasons behind Child labour. Under Article 21-A of the Indian Constitution the State shall provide infrastructure and free resources and compulsory education for children from age six to fourteen years. According to Article 2 of Minimum age (industry) convention of the ILO, 1919 children below the age of 14 are not allowed to be employed in any Public or Private industrial undertaking. The problem of child labour can be reduced to some level by reducing child trafficking, by reducing unemployment, by eliminating poverty. Many financial institutions and World Bank are helping in reducing poverty by providing loans and financial help. Article 15 (3) of Indian constitution made special provisions for child but this doesn't violate right to equality. Despite of making many laws and schemes for reducing child labour still the problem of child labour is completely not finished.

Child labour prohibition and abolition act was passed by Indian government for reducing child labour. So basically child labour is huge problem for India and for the development of India. The future of our country will be in danger if the problem of Child labour is not finished or come to an end. Child labour deprives the children of their childhood by making them work. Child labour is a huge matter of concern which should be controlled as soon as possible.

\section{INTRODUCTION}

Child labour refers to work that is mentally, physically, socially or morally dangerous and harmful to children; and interferes with their activities like schooling by depriving them of the opportunity to attend school; making them to leave school early.

At its highest peak child labour involves children being enslaved, separated them from their families, and forced to work in any harmful activity. All forms of work can be called child labour or not depends on the child's age, the type and the number of hours they work, and the conditions under which it is performed. The answer varies from country to country, as well as among sectors within countries.

Child labor was first recognized and understood as a social problem when factory system came in $18^{\text {th }}$ century in Great Britain. Most European nations made child labour laws by 1940, and World War II bought Children back to child labour. The Child labour became a known issue in the Eastern and Western United States after the Civil war and in the South after 1910. Congressional child labor laws were declar ed unconstitutional by the Supreme Court in 1918 and 1922. A constitution passed an amendment relating to child Labour in Congress in 1924 but the amendment was not approved by enough states. The First Labor Standards Act of 1938 set a minimum age limit of 18 for occupations which are hazardous and 16 
for employment during the school hours and 14 for employment outside school hours. In 1941 The Supreme Court ruled that Congress had $t$ he constitutional authority to pass this act. ${ }^{1}$

\section{ARTICLE 24 OF THE CONSTITUTION OF INDIA}

According to Article 24 of the Indian Constitution no children below the age of 14 years shall be employed to work in any factory or mine or engaged in any other hazardous employment. Article 24 vary from Article 23 in a sense as in Article 23 human trafficking and force labour was banned but the main aim and focus of Article 24 is to protect the rights of the children who are being forced to do any hazardous work to earn money. ${ }^{2}$ For the protection and implementation of the Fundamental right the government has passed The Child Labour (Prohibition and regulation) Act, 1986. This Act provides the rules for the protection prohibition and regulation of Child Labour in the country.

Later in August 2012 the Union cabinet approved a proposal to completely ban employment of children below 14 years in all types of occupations. And now The Child Labour (Prevention and regulation) Act has been amended and now the age of children to work in any hazardous occupation has been increased from 14 to 18 .

Total ban on the Child labour may not be possible so Article 24 puts partial ban on the Child labour.

\section{CAUSES OF CHILD LABOUR}

\section{There are many causes of the Child Labour}

1. Poverty- Due to poverty, illiteracy and unemployment many parents are unable to feed their family and bear the burden so poor parents send their children.

2. Lack of educational facilities- After many years of independence there are still many villages where children and people are deprived of their fundamental rights. Proper education facilities still lacks in many villages. And if there is any, it is miles away. The worst sufferers are the poor families for whom getting their children educated is a dream. Sometimes the lack of affordable

\footnotetext{
${ }^{1} \mathrm{http}: / /$ www.ilo.org/ipec/facts/lang--en/index.htm (23/06/18, $5: 24 \mathrm{pm})$

${ }^{2}$ https://indiankanoon.org/doc/1540780/ (23/06/18, 6:18 pm)
}

school for the education of poor children leaves them illiterate and helpless. Children are forced to live without studying. And sometimes such compulsions push them into the trap of child labour. $^{3}$

3. Social and economic backwardness-Social and economic backwardness of our society is also the main reason behind child labour. Backward families do not send their children to school and consequently, their children are trapped in child labour. They do not have knowledge about the schemes provided by the government for education of children.Lack of education, illiteracy and consequently the lack of awareness of their rights among them leads to the very severe problem of child labour. The conditions of poverty and unemployment give rural families a compulsive basis for engaging children in various tasks. In fact, practices like zamindari system, bandhua majdoori give rise to child labour.

4. Family tradition-It is a bitter truth that in our society it is very easy to give child labour the name of tradition in many families. The traditional family values play their role in increasing the problem of child labour at the voluntary level. Some families also believe that working from childhood onwards will make their children more diligent and worldly-wise in terms of future life. They believe that early employment will give rise to their children's personal development, which will make it easier for them to plan their life ahead. $^{4}$

\section{CHILD LABOUR LAW IN INDIA}

The problem of child labour in India has become a serious issue of concern. The drafting committee of the India constitution wanted to make laws on their own without seeking redressal from any other country in this regard. To prohibit Child labour in India the primitive law was formed and Employment of Children Act, 1938 was passed but this act failed because it failed to address the cause of poverty as poverty is the main reason which drives children into forced labour.

The Indian parliament has again passed Laws and Acts for the protection of Children from Child

\footnotetext{
${ }^{3}$ http://www.indiacelebrating.com/social-issues/child-labour-inindia/ (24/06/18, 4:44 pm)

${ }^{4} \mathrm{http}$ ://www.indiacelebrating.com/social-issues/child-labour-inindia/ (24/06/18, 5:24 pm)
} 
Labour. The Fundamental Rights in India prohibits child labour below the age of 14 years in mines or factory and in any hazardous employment under Article 24. And under Article 21-A of the Indian Constitution the State shall provide infrastructure and free resources and compulsory education for children from age six to fourteen years.

There are some laws under Indian Constitution that governs the protection of Child labour. The Factories Act of 1948 prevents the employment of children below age of 14 years in factory. The Mines Act of 1952 prohibits the employment of Children below the age of 18 years.

\section{HOW TO ELIMINATE CHILD LABOUR}

Child labour is a great problem for our Country. The problem of child labour can be reduced to some extent by abolition of Child trafficking, elimination of poverty, free and compulsory education for all. Many financial institutions like World Bank and International Monetary Fund can help in reducing and removing poverty by providing loan to the developing countries.

1. The foremost reason behind child labour is poverty and to reduce child labour, poverty needs to be reduced first so that people need not have to send their children to earn their livelihood.

2. Increase in education and literacy rate will definitely help in reducing child labour and is a potent weapon against the practice of child labour, because illiterate persons do not know the implications and impact of child labour.

3. Child labour can also be reduced if unemployment is eliminated. Because of unemployment people are not able to fulfill their needs which give rise to child labour. If employment opportunities are increased child labour will be reduced.

4. Child labour is the great problem for our countries future. We need to spread awareness ${ }^{5}$ about the child labour, so that people can understand the evils of child labour. This will help them to know that there is no future of the country if our children are engaged in child labour.

5. There are many laws which prohibit child labour so if we come across any case of child labour we should immediately register our complaint.

\footnotetext{
${ }^{5}$ http://www.indiacelebrating.com/article/article-on-child-labour/ (25/06/18, 6:22 pm)
}
AREAS WHERE
CHILD
RAMPANT
1. Farming
2. As servants at homes
3. Tea stalls
4. Cement factories
5. Diamond Industry
6. Wool- cleaning
7. Shoe polishing
8. Building and construction industry
9. Manufacture of slate pencils
10. Soap manufacture

LABOUR

\section{CONSTITUTIONAL PROVISIONS REGARDING CHILD LABOUR}

There are several articles of Indian constitution that provide protection and provision for child labour.

Article 15(3) - In article 15(3) of the Indian constitution the state is empowered to make special provisions relating to child but it will not violate the right to equality.

Article 21- In article 21 it is stated that no person shall be deprived of his life or personal liberty, except according to procedure established by law.

Article 24- This article simply states Prohibition of Employment of Children in Factories, etc

In article 24 it is stated that no child below the age of 14 shall be employed in any factory or mine and should not be engaged in any hazardous employment.

Hazardous employment can be considered as construction work, match boxes, and fireworks.

Article 39(e) - The State shall in particular, direct its policy towards securing the health and strength of the tender age of children are not abused and that citizens are not forced by economic necessity to enter avocations unsuited to their age or strength. ${ }^{6}$

\section{JUDGEMENT REGARDING CHILD LABOUR}

1. Unni Krishnan Vs Andhra Pradesh - In this case Supreme Court held that children up to the age of 14 had a fundamental right to free education.

http://shodhganga.inflibnet.ac.in/bitstream/10603/8530/16/16_ch apter\%208.pdf ( 27/06/18 9:18 PM) 
2. Neeraja Chaudhary Vs State of Madhya Pradesh AIR 1984 SCC (3) 243)-Provision for rehabilitation should be made for child Labours and they should be rescued this was the judgment given by Supreme Court in this case. ${ }^{7}$

3. Sheela Barse Vs Secretary, Children Aid Society and Others, 1987-In this case the statement was given by Supreme Court that" If there be no proper growth of children of today, the future of the country will be dark". It is the obligation of every generation to bring up children who will be citizens of tomorrow in a proper way.

4. U.P. Bandhua Mukti Morcha Vs Union of India AIR 1984 SC 802-In this case the Supreme Court of India stated if no steps are taken by government under Bonded Labour System Act- 1976 than it would be a violation of Article 23 of the Indian Constitution which states that children should not be forced to work at cheap wages due to their social or economical disadvantage. ${ }^{8}$

5. M.C. Mehta Vs State of Tamil Nadu, 1991Supreme Court has not allowed children to work in a prohibited occupation. According to the judges, "the provisions of Article 45 in the Directive principles of state Policy has still remained a far cry and according to this provision all children up to the age of 14 years are sponsored to be in school, economic necessity forces grown up children to seek employment.

\section{DPSP and Child Labour}

There are many provisions about Children welfare but still our country face severe problem of Child Labour. Directive Principles of State Policy provides many opportunities and facilities to Children for their bright future and development in health manner. Our Constitution provides Fundamental Rights against Exploitation of Children. Our Law of the land says that no children below the age of 14 years should not work in any mines and industry which are hazardous to their health.

There are many cases where it is the attitude of the parents that is not helpful in the elimination of child labour in India. Parents force their children to work

https://indiankanoon.org/search/?formInput=cases $\% 20$ on $\% 20 \mathrm{chi}$ ld\%20labour ( 28/06/ 18 12:14 PM)

\footnotetext{
${ }^{8}$ https:/www.youthkiawaaz.com/2017/05/progressive-supremecourt-judgements/ ( 1/07/18 1:18 PM)
}

and earn money so that they can contribute to the family income. Poverty, Child Labour and unemployment go hand to hand. Without the willingness and awareness the problem of Child Labour cannot be reduced.

\section{Current Scenario of Child Labour}

India is one of the leading countries in Asia which has 33 million children employed in various forms of Child labour. It is shocking that world's largest democracy is yet to ratify the Minimum age convention 1973 (No 138) of the International labour organization (ILO) that lays down grounds rules for employment of minors across the globe.

Article 2 of the Minimum age (industry) convention of the ILO, 1919 which has been ratified by India does not allow children under 14 to be employed in any public or private industrial undertaking, does not even apply for India. ${ }^{9}$ Due to socio and economic problems the code of child centeredness was replaced by neglect, abuse and deprivation. The root of child labour is poverty. If poverty is reduced in India than child labour will automatically be reduced. There are criminal laws also which are made for the protection and benefit of children. ${ }^{10}$

\section{CONCLUSION}

Our government took many measures to reduce Child labour. There are many laws and regulatory department for child labour, yet it is ineffective in controlling child labour. ${ }^{11}$ This is possible only when there is a cooperation of all the sections of the society and the law enforcement agencies and by removing or minimizing the causes of child labour. The main thrust should be on controlling the population of the country, education of the children and providing sufficient fund for its removal from the gross domestic product of India.

The consequences of child labour are very harsh as children are deprives of their childhood. Hence the problem of child Labour should be as soon as possible reduced.

\footnotetext{
${ }^{9}$ https://www.legalindia.com/child-labour-in-india-presentscenario/ ( 2/07/18 6:19 PM)

${ }^{10} \mathrm{https}: / /$ mahenkads.wordpress.com/2011/12/01/currentscenarios-of-child-labor-in-india/ ( 2/07/ 7:01 PM)
}

11

http://shodhganga.inflibnet.ac.in/bitstream/10603/8530/19/19_ch apter\%2011.pdf ( 3/ 07/ 18 10:12 AM) 